\title{
Aaron Brody. " 'For the wealth of the Sea Will Pass on to You': Changes in Patterns of Trade from Southern Phoenicia to Northern Judah in the Late Iron Age and Persian Periods"
}

\section{Maria Gabriella Micale}

\section{(2) OpenEdition}

\section{Journals}

Electronic version

URL: https://journals.openedition.org/abstractairanica/53392

DOI: $10.4000 / a b s t r a c t a i r a n i c a .53392$

ISSN: 1961-960X

Publisher:

CNRS (UMR 7528 Mondes iraniens et indiens), Éditions de l'IFRI

Electronic reference

Maria Gabriella Micale, "Aaron Brody. " 'For the wealth of the Sea Will Pass on to You': Changes in Patterns of Trade from Southern Phoenicia to Northern Judah in the Late Iron Age and Persian Periods"'", Abstracta Iranica [Online], Volume 42-43 | 2021, document 46, Online since 30 December 2021, connection on 24 December 2022. URL: http://journals.openedition.org/abstractairanica/53392 ; DOI: https://doi.org/10.4000/abstractairanica.53392

This text was automatically generated on 24 December 2022.

All rights reserved 


\title{
Aaron Brody. " 'For the wealth of the Sea Will Pass on to You': Changes in Patterns of Trade from Southern Phoenicia to Northern Judah in the Late Iron Age and Persian Periods"
}

\author{
Maria Gabriella Micale
}

\section{REFERENCES}

Aaron Brody. " 'For the wealth of the Sea Will Pass on to You': Changes in Patterns of Trade from Southern Phoenicia to Northern Judah in the Late Iron Age and Persian Periods" in A. Gilboa, A. Yasur-Landau (eds.). Nomads of the Mediterranean: Trade and Contact in the Bronze and Iron Ages. Studies in Honor of Michal Artzy (Culture and History of the Ancient Near East 112). Brill: Leiden, 2020, p.69-80.

1 In the volume honoring Michal Artzy's career, A. Brody revisits the fragment of an object from Tell en-Nasbeh (12 km northwest of Jerusalem) initially published in 1947 that he recognizes as the fragment of a Phoenician mask or protoma. Even though it is not announced in the title of the article, this object lies at the very center of Brody's discussion. In the Author's interpretation, this fragment is a new and important element (in addition to others he already discussed in the past) in the reconstruction of patterns of trade between the Levantine coastal region and the Judean Highlands between Iron Age II and the Persian Period.

2 Phoenician masks often come from the Levantine coast, including Syria and Lebanon, but according to the A.'s reconstruction, the mask from Tell en-Nasbeh represents the 
only specimen from the Persian period Judah. The clay fabric and the petrographic analysis of a comparable object suggest a southern Lebanese origin. Its typological identification arrives from the iconographic comparison with some images of Bes as well as of Satyrs. The chronological attribution of the fragment seems to be quite uncertain, beginning with the first publication of its discovery context in early 20th century. However, the A. often speaks of "early Persian period"; he asserts that the materials from the room where the fragment was found cannot be either later than the Persian period nor earlier than Iron Age II, while confirming that the Tell en-Nasbeh Persian settlement ends around 450-420 BC.

3 A single fragment from a unique object (apparently unparalleled for its chronology and regional context) may seem too little to be able to contribute to the portrait of the local and inter-regional trade paths between the end of the Iron Age and the Persian Period, as the A. proposes. The A. tempts to describe the diverse trajectories through which the object has arrived to Tell en-Nasbeh, although the paths and mechanisms of delivery of goods from the coast to the hill country remains for the most part unclear.

4 However, should this piece actually be part of an original satyr mask, the presence of this Phoenician item at Tell en-Nasbeh, together with some other objects that the A. reconnects to the existence of wine-drinking and commensal events (i.e. Greek symposia), could be effectively relevant in terms of examining social attitudes within a household and within the wider local community. A more precise chronological definition of the fragment as well as of the materials from the same context would help us in defining the introduction of a feasting event into the local culture, and to understand if the Persian Period saw the introduction of this new social performance or, conversely, was responsible for its end.

\section{AUTHORS}

\section{MARIA GABRIELLA MICALE}

Freie Universität Berlin 